\title{
ПЕДАГОГІЧНА МОДЕЛЬ ФОРМУВАННЯ ПРОФЕСІЙНО-МОВЛЕННЕВОЇ КОМПЕТЕНТНОСТІ МАЙБУТНІХ СУДНОВОДІЇВ
}

\begin{abstract}
Принципово важливим у державних документах (Законі Украйни «Про вищу освіту», Національній доктрині розвитку освіти України у ХХІ столітті, Національній стратегії розвитку освіти в Украӥні на 2012-2021 роки) визначено розроблення теоретичного базису та інноваційних методів професійної підготовки майбутніх фахівиів. Неабиякого значення в изьому аспекті набуває оптимізачія підготовки саме майбутніх фахівиів морського профілю, зокрема судноводії, оскільки ї̈ розв 'язання суттєво впливає на розвиток економічного потенціалу України. Сьогодні перед сучасним фахівцем морського профілю постають нові вимоги до особистісних і професійних якостей, насамперед швидкості ухвалення оптимальних рішень в екстремальних умовах та їх донесення до членів команди, сочіальної взаємодії в поліетнічному екіпажі, ефективної комунікації, має ефективно аналізувати значну кількість міжнародних нормативних документів світової індустрії, саме тому система вищої морської освіти вимагає ефективної підготовки висококваліфікованих фахівців із глибокими професійно значущчими знаннями, обов 'язковим володінням українською та іноземною мовами. У статті розглядається педагогічна модель формування професійно-мовленнєвої компетентності майбутніх судноводіїв. Вона має такі етапи та відповідні їм методи й форми навчально-пізнавальної діяльності: адаптаційно-підготовчий (методи: самостійні завдання (аналітичні та репродуктивні), бесіди з відомими фахівиями, ігрове моделювання, телекомунікація (проведення телемостів), форми: самостійна робота студентів, позааудиторні заняття, спецсемінар, розмовний клуб), навчально-творчий (методи: творчі завдання (індивідуально-творчі, колективно-творчі), проєктування, олімпіади; формами були такі: навчально-дослідницька діяльність, студентські конферениії, коворкінг, позааудиторні заняття), продуктивно-технологічний (метод: кейс-стаді, тренінгові, інтерактивні, інформаційні технології; формами були практичні заняття, науково-дослідна діяльність курсантів), рефлексивно-корекиійний (самоаналіз й самооцінювання на засіданнях розмовного клубу, анкетування, тестування).
\end{abstract}

Ключові слова: майбутні судноводії, експериментальна робота, модель, методи, форми.

Yevheniia BONDARENKO, orcid.org/0000-0003-4802-2228

Candidate of Pedagogical Sciences, Teacher at the English Department № 2 National University "Odesa Maritime Academy"

(Odesa, Ukraine) bndevgeniya@gmail.com

\section{PEDAGOGICAL MODEL OF THE FORMATION OF THE PROFESSIONAL AND SPEECH COMPETENCE OF FUTURE NAVIGATORS}

According to governmental documents (Law of Ukraine "On Higher Education", The National Doctrine of Education Development of Ukraine in the XXI century, National Strategy for Education Development in Ukraine for 2012-2021) it is identified the development of theoretical basis and innovative methods of training future professionals. As a result, in this aspect the optimization of training future marine specialists, especially navigators, is taken a great importance as its solution significantly effects on the Ukrainian development of the economy opportunity. It is shown that new requirements are arisen before the modern specialist as to personal and professional qualities, firstly, taking optimal decisions in extreme conditions and reporting to the crew members, social interaction in polyethnic crew and effective communication, which is why the system of higher marine education requires effective preparation of highly skilled specialists with deep professional knowledge and also it is compulsory to possess Ukrainian and foreign languages. The article considers the pedagogical model of formation of the professional and speech competence of future navigators. It has the following stages and corresponding methods and forms of educational-cognitive activities: adaptive-preparatory (methods: specific tasks (analytical, reproductive),conversations with famous specialist, simulation, and telecommunications (teleconference); forms: self-studying, extracurricular activities, specialized seminar, conversational club); educationalcreative (methods: creative tasks (individual, collective), designing and competitions; forms were: (educational research 
activities, student's conferences, co-working and extracurricular activities); productive-technological (methods: casestudy, training technologies and information technology; forms were practical classes and cadet's research activities); reflexive-correctional (self-evaluation and correction during conversational club questionnaire and testing).

Key words: future navigators, experimental work, model, methods, forms.

Постановка проблеми. Одним із принципово важливих завдань підготовки майбутніх фахівців, зокрема судноводіїв, є формування їхньої професійно-мовленнєвої компетентності. Розв' язання цієї проблеми впливає на розв'язання таких питань, як поліпшення соціальної взаємодії в поліетнічному екіпажі, підвищення професіоналізму курсанта, формування його компетентності саморозвитку.

Аналіз досліджень. Варто наголосити, що принципова увага науковців акцентувалася на таких напрямах дослідження зазначеної проблеми, як формування в майбутніх фахівців, зокрема й судноводіїв, іншомовного професійного мовлення (Барсук, 2016), готовності до професійної діяльності (Кулакова, 2006), зокрема й у контексті компетентнісного підходу (Князян, 2019; Слюсаренко, 2014).

Водночас зазначимо, що проблема розроблення цілісної моделі формування професійномовленнєвої компетентності майбутніх судноводіїв вимагає грунтовного висвітлення.

Метою статті $\epsilon$ висвітлення етапів, методів і форм педагогічної моделі з формування професійно-мовленнєвої компетентності курсантів.

Виклад основного матеріалу. Насамперед варто наголосити, що професійно-мовленнсва компетентність віддзеркалює переконання майбутніх судноводіїв у важливості володіння українською та англійською мовами за професійним спрямуванням, знання про норми мови, вміння в аудіюванні, говорінні, читанні, письмі з огляду на особливості їхньої професійної діяльності, здатність до комунікативної взаємодії в багатокультурному просторі, співпраці, рефлексії та корекції свого мовлення.

Провідними компонентами структури професійно-мовленнєвої компетентності майбутніх судноводіїв $є$ мотиваційно-аксіологічний, когнітивно-знаннєвий, діяльнісно-процесуальний.

Зазначимо, що мотиваційно-аксіологічний компонент відображає прагнення до активного життя, цікавої роботи як ціннісної орієнтації, інтерес до професійної діяльності, бажання стати висококваліфікованим спеціалістом, переконання у важливості володіння культурою українськомовного та англомовного спілкування. Когнітивно-знаннєвий компонент віддзеркалює знання трьох блоків: блок лінгвістичних знань (про відповідність мовлення усталеним у суспільстві мовним нормам (орфоепічним, граматичним, лексичним, стилістичним), про правильність, діапазон, швидкість, взаємо- дію, зв'язність мовлення; блок соціолінгвістичних знань (про етикет, культуру, традиції різних народів); блок фахових знань (про особливості професійної діяльності судноводія, які актуалізуються в його мовленні). Діяльнісно-процесуальний компонент відбиває вміння: мовленнєві (вміння в аудіюванні, говорінні (монологічному, діалогічному), читанні, письмі з проєкцією на специфіку професійної діяльності судноводіїв), інтерактивні (вміння взаємодіяти в процесі комунікації з членами багатонаціонального екіпажу, представниками офіційних організацій), конвіктивні (вміння вселяти впевненість, рішучість, переконувати інших рухатися до спільної мети в командній діяльності, у необхідності особистісно-професійного саморозвитку), рефлексивно-корекційні (вміння рефлексії та корекції свого мовлення).

Переходячи до характеристики моделі, зазначимо, що вивчення лінгвістичних джерел свідчить, що модель $є$ зразком, який відтворює конструкцію та функціонування певного об'єкта з метою одержання нових знань про нього (Бусел, 2004: 535). У педагогічних джерелах наголошується, що модель відображає суттєві риси системи-оригіналу, іiі структуру. Водночас моделювання передбачає створення моделей, які є аналогами об'єктів, що досліджуються (Безруких, 2003: 146; Бусел, 2004: 323).

Аналіз, систематизація й узагальнення положень науковців щодо структури моделі професійної підготовки майбутніх фахівців дають змогу розробити педагогічну модель формування професійно-мовленнєвої компетентності, упровадження якої відбувається за такими етапами: адаптаційно-підготовчим, навчально-творчим, продуктивно-технологічним, рефлексивно-корекційним етапами.

Метою адаптаиійно-підготовчого етапу було створення інтересу до професійної діяльності, прагнення до активного життя, цікавої роботи як ціннісної орієнтації. Окрім формування мотиваційно-аксіологічного компонента, на цьому етапі інтеріоризувалися лінгвістичні, соціолінгвістичні (частково й фахові) знання когнітивно-знаннєвого компонента, а також мовленнєві й інтерактивні вміння діяльнісно-процесуального компонента, а саме в аудіюванні, говорінні, читанні, письмі (відповідно до персональної, соціальної, навчальної сфер, частково - професійної сфери), взаємодії 3 іншими в процесі бесід, ігрового моделювання, телекомунікації, самостійної роботи. 
Формування цих компонентів передбачалося й на другому етапі - навчально-творчому. Метою зазначеного етапу була активізація бажання стати висококваліфікованим спеціалістом, переконання у значенні культури українськомовного та англомовного спілкування, розширення лінгвістичних, соціолінгвістичних і фахових знань, мовленнєвих, інтерактивних умінь, формування конвіктивних умінь шляхом продукування та реалізації цікавих ідей у спільній діяльності з іншими, проєктуванні, творчості, навчальних дослідженнях.

Продуктивно-технологічний етап мав на меті актуалізацію всіх компонентів професійно-мовленнєвої компетентності, які було сформовано на попередніх етапах, збагачення досвіду фахової діяльності майбутнього судноводія. Зокрема, передбачався вияв усіх складників мотиваційноаксіологічного компонента професійно-мовленнєвої компетентності; лінгвістичних знань відповідно до мовних норм, соціолінгвістичних знань про культурне надбання України, різних країн світу, етикет, а також фахових знань, які використовуються в професійному мовленні судноводія. Водночас активізувалися й уміння в аудіюванні, говорінні, читанні, письмі відповідно до специфіки діяльності фахівця судноводіння.

Метою завершального етапу - рефлексивнокорекиійного - був розвиток умінь проводити діагностику сформованості компонентів професійно-мовленнєвої компетентності, аналізувати власні досягнення, рівень володіння українською, англійською мовами, професійно значущими знаннями, коригувати свій саморозвиток із метою набуття високого рівня сформованості зазначеної компетентності.

У процесі експериментальної роботи, проведеної нами на базі факультету судноводіння Дунайського інституту Національного університету «Одеська морська академія», навчально-наукового інституту морського флоту Одеського національного морського університету, до інструментарію впровадження адаптаційно-підготовчого етапу входили: а) методи: самостійні завдання (аналітичні та репродуктивні), бесіди з відомими фахівцями, ігрове моделювання, телекомунікація (проведення телемостів); б) форми: самостійна робота студентів, позааудиторні заняття, спецсемінар, розмовний клуб; в) засоби: навчальний посібник, автентичні матеріали, телевізори, комп'ютери.

Самостійні завдання в межах самостійної роботи студентів були систематизовані відповідно до двох груп: аналітичні та репродуктивні. До аналітичних віднесли ті, які передбачали аналіз, опрацювання нової інформації, підготовку есе аналітичного характеру, доповідей, доповідей- презентацій, а також пресконференцій як інтерактивного виду організації повідомлень; до самостійних репродуктивних завдань - проведення дискусій щодо розв'язання певних проблем, продукування ідей та захист їхньої доцільності, розроблення рекомендацій. Зазначені завдання впроваджувалися протягом проведення спецсемінару «Професійно-мовленнєва компетентність у діяльності судноводія» та практичних занять із навчальних дисциплін «Ділова українська мова», «Англійська мова за професійним спрямуванням», «Історія та культура України». У позааудиторній діяльності був організований розмовний клуб «Speaking Maritime English Club» (SMEC), який передбачав вправи і завдання, спрямовані на розвиток діалогічного та монологічного мовлення, на вміння опрацьовувати автентичні професійно-орієнтовані матеріали: тексти, відео та аудіо. Також було проведено бесіди з відомими фахівиями, протягом яких курсанти обговорювали різноманітні ситуації, що мають місце у професійній діяльності судноводіїв. Наголосимо, що спочатку фахівець пропонував проблему, курсанти висловлювали свої варіанти ії розв'язання, які й обговорювали із запрошеним гостем. Темами були, наприклад, такі: «Особливості реалізації управлінських рішень у багатонаціональному колективі», «Особистісні якості, які актуалізуються під час аварійних ситуацій та отримання сигналу лиха на морі». Для формування інтересу до професійної діяльності, прагнення здобути високу кваліфікацію, асиміляції курсантами знань, умінь і досвіду використання фахової, лінгвістичної, соціолінгвістичної інформації було запропоновано ігрове моделювання. У процесі його впровадження спостерігалася проєкція нових знань, які засвоювалися, на контекст майбутньої професії. Неабияк активізувало професійно-мовленнєву компетентність телеспілкування курсантів різних філіалів Національного університету «Одеська морська академія», зокрема, з Одеси й Маріуполя. Цінність цього методу полягала саме в можливості живого, прямого обміну досвідом найкращої організації та самоорганізації навчання, плавпрактики, дозвілля тощо.

На навчально-творчому етапі реалізовувалися такі методи: творчі завдання (індивідуальнотворчі, колективно-творчі), проєктування, олімпіади. Формами були такі: навчально-дослідницька діяльність, студентські конференції, коворкінг, позааудиторні заняття; засобами - навчальний посібник, автентичні матеріали, мережа Інтернет, комп'ютери. Індивідуально-творчі завдання мали на меті вибір курсантами нестандартних підходів до розв'язання проблем у процесі кому- 
нікації на судні. Колективно-творчі завдання передбачали раціоналізацію відомого, внесення інновацій із метою поліпшення діяльності не лише в аспекті взаємодії всередині екіпажу, а й 3 компаніями та фірмами - партнерами, контролювальними органами тощо. Більш активний вияв творчої ініціативи спостерігався в контексті проєктної діяльності, яку було організовано у вищому навчальному закладі у форматі коворкінгу. Проєктна діяльність виступала засобом формування у майбутніх судноводіїв мовленнєвих, інтерактивних, конвіктивних, рефлексивнокорекційних умінь у процесі розв'язання певної проблеми 3 отриманням конкретного матеріального продукту цієї діяльності. Коворкінг курсантів передбачав взаємодію, співтворчість у процесі проєктної діяльності, оскільки саме ця форма організації навчально-пізнавальної праці давала змогу синтезувати знання різних навчальних дисциплін під час спілкування майбутніх фахівців між собою, обміну досвідом і знаннями. Навчально-дослідницька діяльність сприяла активізації творчості у процесі інтеріоризації лінгвістичних, соціолінгвістичних, фахових знань, формування мисленнєвих умінь, оволодіння методами дослідження в галузі судноводіння, розвитку інтересу до професійної діяльності, креативних здібностей. Найкращі роботи, виконані курсантами як навчально-дослідницькі, висувалися на участь у студентських науковопрактичних конференціях, що також впливало на формування професійно-мовленнєвої компетентності, оскільки вимагало публічного виступу, повних і коректних відповідей на запитання, участі в дискусіях, вміння доводити правильність і наукову цінність своїх ідей. Курсанти активно брали участь і в предметних олімпіaдаx 3 української та англійської мов.

Продуктивно-технологічний етап реалізовувався за допомогою таких методів, як кейс-стаді, тренінгові, інтерактивні, інформаційні технології; формами були практичні заняття, науководослідна діяльність курсантів; засобами - мережа Інтернет, комп'ютери, автентичні матеріали. Keйс-стадi передбачала використання ситуаційного навчання, під час якого викладач розвивав систему фахових, лінгвістичних і соціолінгвістичних знань курсантів, їхне мислення, створював реальну професійну атмосферу, у якій актуалізувалися мовленнєві, інтерактивні, конвіктивні, рефлексивно-корекційні вміння. Тренінгові технологіï були одним $з$ ефективних методів формування лінгвістичних, соціолінгвістичних і фахових знань курсантів. Інтерактивні методи навчання були спрямовані на актуалізацію окреслених знань і вмінь, а також на розвиток якостей майбутнього судноводія (швидкість реагування в різних ситуаціях, самостійність, наполегливість тощо). Під час занять викладач використовував і різні навчальні інформачійні технології, представлені у форматі комп'ютерних програм, наприклад такі, як-от: NetClass Pro, MarEng Plus, Marlins Test, Leonardo da Vinci, N.E.P.T.U.N.E. (Naval English Practical Training Using New E-learning) тощо. Важливою формою, у якій забезпечувалося формування професійно-мовленнєвої компетентності, була науково-дослідницька діяльність майбутніх фахівців, яка передбачала широку актуалізацію накопичених лінгвістичних, соціолінгвістичних, фахових знань та їх наступне розширення відповідно до тематики дослідження.

На рефлексивно-корекційному етапі проводилися самоаналіз, самооцінювання, корекція професійно-мовленнєвої компетентності. На цьому етапі було доцільним організовувати як скорочені, так і розгорнуті варіанти самоаналізу й самооцінювання, водночас скорочені варіанти нами пропонувалися, наприклад, на кожному засіданні розмовного клубу (вони містили тести на перевірку граматичних, лексичних, фахових знань і на володіння видами мовленнєвої діяльності); розгорнуті тести містили анкети на оцінювання в собі прагнення до саморозвитку, цінності навчально-професійної діяльності.

Метою контрольного експерименту було вивчення й пояснення кількісних і якісних змін, отриманих під час експериментальної роботи відповідно до визначених критеріїв і показників сформованості професійно-мовленнєвої компетентності майбутніх судноводіїв. На основі отриманих результатів визначено узагальнені дані за всіма критеріями оцінювання сформованості професійно-мовленнєвої компетентності (див. табл. 1).

Як видно 3 таблиці 1, до початку проведення експериментальної роботи рівень сформованості професійно-мовленнєвої компетентності був майже однаковим в експериментальній і контрольній групах. Після проведення експерименту в експериментальній групі спостерігалася позитивна динаміка рівнів: високий рівень був виявлений майже у третини - 31,3\% респондентів (було 12,3\%), середній - 52,3\% (було 24,7\%), низький - 16,4\% (було 63,0\%). У контрольній групі високого рівня досягли $18,2 \%$ (було 14,5\%), середнього - 32,8\% (було 25,5\%), низького - 49,0 (було - 60,0\%).

Був використаний критерій Пірсона $\left(\chi^{2}\right)$ для підтвердження відсутності статистичних відмінностей між контрольною й експериментальною вибірками до початку експерименту. Натомість 


\section{Узагальнені результати рівнів сформованості професійно-мовленнсвої компетентності в експериментальній та контрольній групі за констатувальним і контрольним етапами експерименту}

\begin{tabular}{|c|c|c|c|c|}
\hline \multirow{2}{*}{$\begin{array}{c}\text { Рівні сформованості } \\
\text { професійно-мовленнсвої } \\
\text { компетентності }\end{array}$} & \multicolumn{2}{|c|}{ Експериментальна група } & \multicolumn{2}{|c|}{ Контрольна група } \\
\hline & $\begin{array}{c}\text { Констатувальний } \\
\text { етап }\end{array}$ & $\begin{array}{c}\text { Контрольний } \\
\text { етап }\end{array}$ & $\begin{array}{c}\text { Констатувальний } \\
\text { етап }\end{array}$ & $\begin{array}{c}\text { Контрольний } \\
\text { етап }\end{array}$ \\
\hline Високий & $12,3 \%$ & $31,3 \%$ & $14,5 \%$ & $18,2 \%$ \\
\hline Середній & $24,7 \%$ & $52,3 \%$ & $25,5 \%$ & $32,8 \%$ \\
\hline Низький & $63,0 \%$ & $16,4 \%$ & $60,0 \%$ & $49,0 \%$ \\
\hline Усього & $100 \%$ & $100 \%$ & $100 \%$ & $100 \%$ \\
\hline
\end{tabular}

наприкінці формувального етапу експерименту результати обчислення за цим критерієм підтвердили статистичну значущість відмінності експериментальної групи від контрольної групи, що підтвердило ефективність теоретично обгрунтованої та експериментально перевіреної моделі 3 формування професійно-мовленнєвої компетентності майбутніх судноводіїв.

Висновки. Ефективність формування професійно-мовленнєвої компетентності забезпечується за умов упровадження педагогічної моделі, яка має такі етапи та відповідні їм методи й форми навчально-пізнавальної діяльності: адаптаційнопідготовчий (методи: самостійні завдання (аналітичні та репродуктивні), бесіди 3 відомими фахівцями, ігрове моделювання, телекомунікація (проведення телемостів); форми: самостійна робота студентів, позааудиторні заняття, спецсемінар, розмовний клуб), навчально-творчий (методи: творчі завдання (індивідуально-творчі, колективнотворчі), проєктування, олімпіади; формами були такі: навчально-дослідницька діяльність, студентські конференції, коворкінг, позааудиторні заняття), продуктивно-технологічний (метод: кейс-стаді, тренінгові, інтерактивні, інформаційні технології; формами були практичні заняття, науково-дослідна діяльність курсантів), рефлексивно-корекційний (самоаналіз й самооцінювання на засіданнях розмовного клубу, анкетування, тестування).

Перспективи подальших розвідок у цьому напрямі полягають у розробленні педагогічних моделей формування науково-пізнавальної, інтеркультурної, соціальної та інших компетентностей майбутніх фахівців судноводіння.

\section{СПИСОК ВИКОРИСТАНИХ ДЖЕРЕЛ}

1. Барсук С. Л. Модель формування іншомовного професійного діалогічного мовлення майбутніх судноводіїв. Hayчные труды SWord. Вып. 3 (44). Т. 4. Иваново : Научный мир, 2016. С. 68-74.

2. Великий тлумачний словник сучасної української мови / В. Т. Бусел. Київ ; Ірпінь : ВТФ «Перун», 2004. С. 1440.

3. Кулакова М. В. Формування готовності до професійної діяльності в майбутніх фахівців у вищих морських навчальних закладах : дис. ... канд. пед. наук : спец. 13.00.04. Одеса, 2006. С. 225.

4. Педагогический энциклопедический словарь / М. М. Безруких, В. А. Болотов, Л. С. Глебова. Москва : Большая Российская энщиклопедия, 2003. С. 528.

5. Слюсаренко Н. В. Формування соціокультурної особистості майбутнього судноводія на засадах компетентнісного підходу. Людинознавчі студії. Педагогіка. 2014. Вип. 29 (1). С. 173-181.

6. Kniazian, M. \& Khromchenko, O. The ESP Lecturers' Self-Development Competence in Higher Educational Context. The Journal of Teaching English for Specific and Academic Purposes. 2019. Vol. 7. No 3. P. 385-393. URL: https://doi.org/10.22190/JTESAP1903385K.

\section{REFERENCES}

1. Barsuk S. L. Model formufannya inschomovnogo profesijnogo dialogichnogo movlennya majbutnich sudnovodiiv. [Teaching model to develop future seafarers communication skills]. Scientific works Sword. Vip. 3 (44). T. 4. Ivanovo : Nauchnij mir, 2016. S. 68-74 [in Ukrainian].

2. Velikij tlumachnij slovnik ukrainskoi movi. [Large explanatory dictionary of the modern Ukrainian language]. V. T. Busel. K. ; Irpin: VTF "Perun", 2004. S. 1440 [in Ukrainian].

3. Kulakova M. V. Formuvannya gotovnosti do profesijnoi diyalnosti v maybutnih fahivciv u vishih morskih navchalnih zakladah [Development of the future specialists' readiness to professional activity at higher marine educational establishments]. dis....kand. ped. nauk: spec. 13.00.04. Odesa, 2006. S. 225 [in Ukrainian].

4. Pedagogicheskij enciklopedicheskij slovar. [Pedagogical encyclopedic dictionary]. M. M. Bezrukih, V. A. Bolotov, L. S. Glebova. M.: Big Russian Encyclopedia, 2003. S. 528 [in Russian].

5. Slusarenko N. V. [Formation of sociocultural personality of the future navigator through the competence-based approach]. Human Studies. Series of Pedagogy. 2014. Vip. 29 (1). S. 173-181 [in Ukrainian].

6. Kniazian, M. \& Khromchenko, O. The ESP Lecturers' Self-Development Competence in Higher Educational Context. The Journal of Teaching English for Specific and Academic Purposes. 2019. Vol. 7. No 3. P. 385-393. URL: https://doi.org/10.22190/JTESAP1903385K [in English]. 